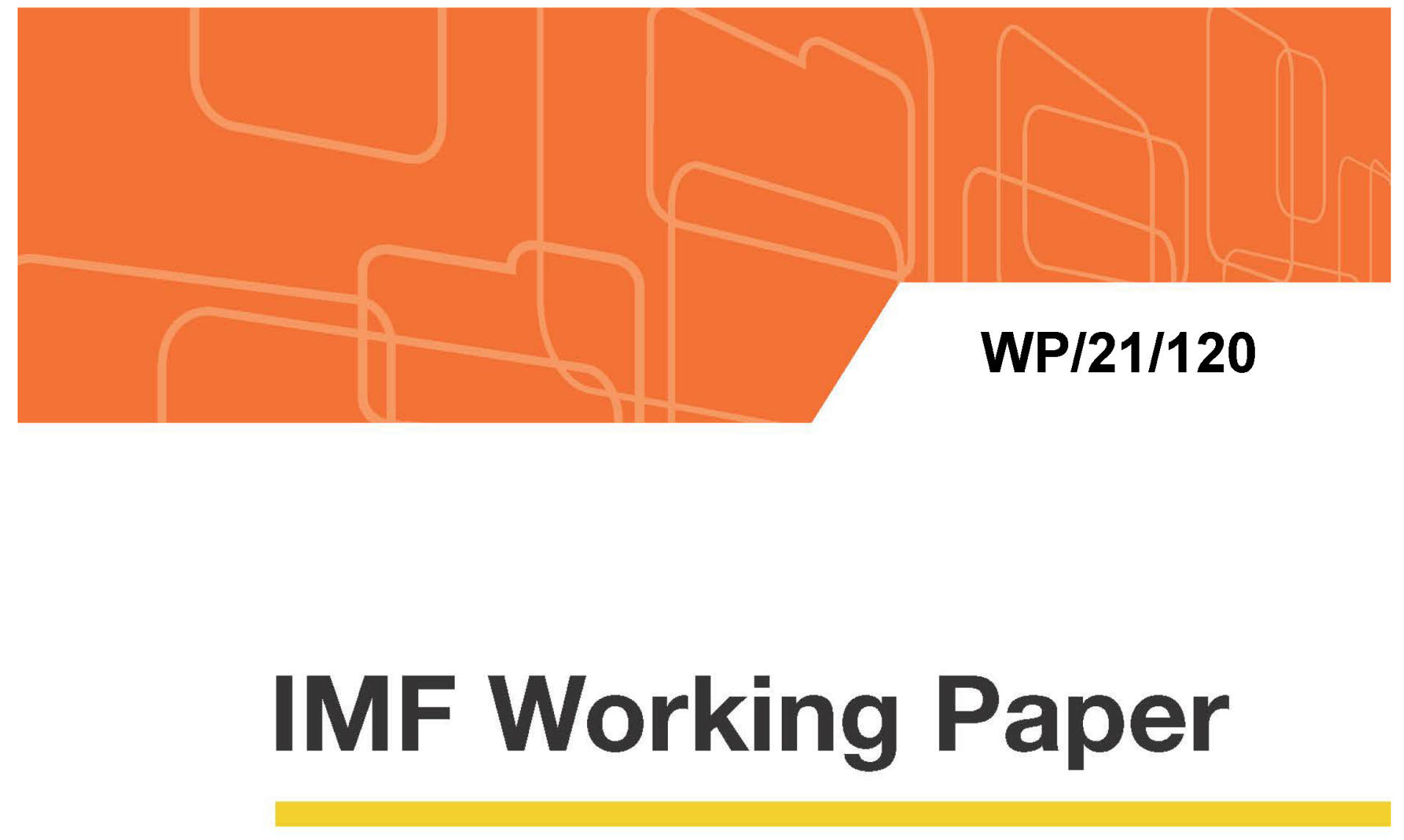

\title{
The Rise in Inequality after Pandemics: Can Fiscal Support Play a Mitigating Role?
}

by Davide Furceri, Prakash Loungani, Jonathan D. Ostry, and Pietro Pizzuto

IMF Working Papers describe research in progress by the author(s) and are published to elicit comments and to encourage debate. The views expressed in IMF Working Papers are those of the author(s) and do not necessarily represent the views of the IMF, its Executive Board, or IMF management.

$$
\text { I N T E R N A T I O N A L M O N E T A R Y F U N D }
$$




\title{
IMF Working Paper
}

Asia and Pacific Department and Independent Evaluation Office

\section{The Rise in Inequality after Pandemics: Can Fiscal Support Play a Mitigating Role?}

\author{
Prepared by Davide Furceri, Prakash Loungani, Jonathan D. Ostry, and Pietro Pizzuto
}

Authorized for distribution by Jonathan D. Ostry and Prakash Loungani

April 2021

IMF Working Papers describe research in progress by the author(s) and are published to elicit comments and to encourage debate. The views expressed in IMF Working Papers are those of the author(s) and do not necessarily represent the views of the IMF, its Executive Board, or IMF management.

\begin{abstract}
Major epidemics of the last two decades (SARS, H1N1, MERS, Ebola and Zika) have been followed by increases in inequality (Furceri, Loungani, Ostry and Pizzuto, 2020). In this paper, we show that the extent of fiscal consolidation in the years following the onset of these pandemics has played an important role in determining the extent of the increase in inequality. Episodes marked by extreme austerity — measured using either the government's fiscal balance, health expenditures or redistribution - have been associated with an increase in the Gini measure of inequality three times as large as in episodes where fiscal policy has been more supportive. We survey the evidence thus far on the distributional impacts of the COVID-19 pandemic, which suggests that inequality is likely to increase in the absence of strong policy actions. We review the case made by many observers (IMF 2020; Stiglitz 2020; Sandbu 2020b) that fiscal support should not be withdrawn prematurely despite understandable concerns about high public debt-to-GDP ratios.

JEL Classification Numbers: E6, H6, I14, O15

Keywords: inequality; pandemics; fiscal support; austerity.
\end{abstract}

Author's E-Mail Address: DFurceri@imf.org; PLoungani@imf.org; Jostry@imf.org; pietro.pizzuto02@unipa.it. 


\section{Table of Contents}

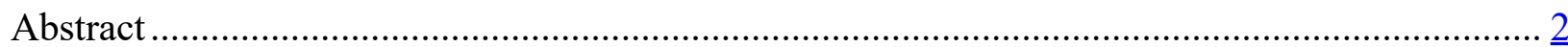

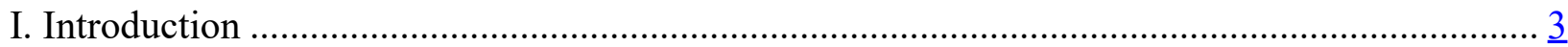

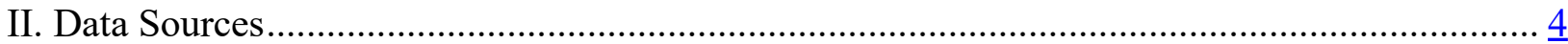

III. Pandemics and inequality: A review of the Evidence ……………………………………..... $\underline{6}$

A. Evidence from Historical Pandemics .................................................................................. $\frac{6}{6}$

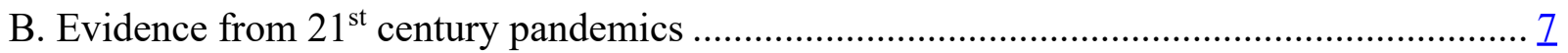

C. Distributional impacts of COVID-19: Early evidence …………........................................ $\underline{8}$

IV. Pandemics and Inequality: Role of the Fiscal Response ................................................... 10

A. Pandemics, Inequality and Austerity ……………….............................................. $\frac{10}{12}$

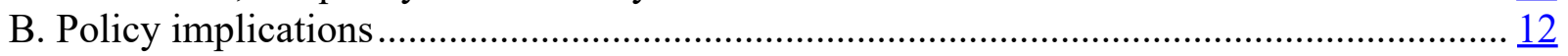

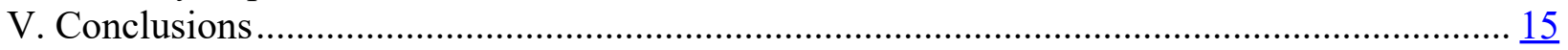

Figures

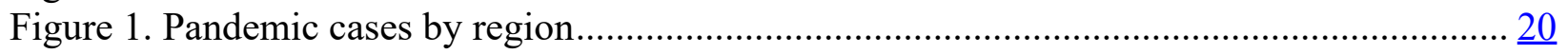

Figure 2. Impact of pandemics on market and net Gini and redistribution ............................... 21

Figure 3. Impact of pandemics on general government fiscal balance.................................... 22

Figure 4. Impact of pandemics on health expenditures .......................................................... 23

Figure 5. Impact of pandemics on net Gini: the role of the fiscal response …………………..... 24

Tables

Table 1. Spread and severity of pandemics: summary statistics.............................................. 25

Table 2. Data sources and descriptive statistics....................................................................... 25 


\section{INTRODUCTION}

The COVID-19 pandemic has led to a worldwide fiscal response estimated at nearly $\$ 12$ trillion or about 12 percent of global GDP (IMF 2020). Roughly half is in the form of budget support - additional spending or forgone revenue - and the other half in the form of liquidity support and equity injections by the public sector. While nearly all governments have provided such support, advanced economies account for the bulk of it, as they have the fiscal space to finance larger deficits, and their central banks have been able to help through purchases of government or corporate securities. The fiscal response in low-income developing countries has been restricted by tighter financing constraints.

Despite this fiscal support, the pandemic has upended the lives of millions around the globe, with evidence suggesting that those in low-income deciles and minority groups-which, sadly, often overlap — are disproportionately hurt. Dosi, Fanti and Virgillito (2020) enumerate the many channels through which the pandemic can end up amplifying existing inequalities, ranging from inequities in risk of contagion, access to hospitalization, possibility to work remotely, and risk of longer-term job loss. Evidence suggests that each of these channels has been operative during the COVID-19 pandemic, suggesting that it is likely to lead to an increase in inequality (Furceri, Loungani, Ostry and Pizzuto, 2020).

Though the pandemic is far from over, the fiscal support provided, combined with the effects of declines in output and government revenue, has pushed public debt to 100 percent of GDP in 2020 globally, the highest level since 1880 according to IMF estimates (IMF 2020). In advanced economies, the debt-to-GDP ratio is over 120 percent, higher than the level at the end of World War II; in emerging markets, the debt-to-GDP ratio is over 60 percent, higher than the previous peak in the mid-1980s. Over half of low-income countries were considered to be in or at high risk of debt distress as of September 2020.

A number of observers have urged caution in withdrawing fiscal support too soon despite the build-up in debt levels. The IMF's Fiscal Monitor enjoins that "governments should ensure that lifelines are not withdrawn too rapidly" (IMF 2020):

"We believe there is a risk of prematurely withdrawing fiscal support and policymakers that have a choice would be well-advised to be very gradual and to maintain fiscal support until the recovery is on a sound footing." (Vitor Gaspar, Financial Times, October 14, 2020) 
Stiglitz (2020) calls for empathy and support from creditors for the plight of low-income countries where the effects of the pandemic have helped pushed debt to unsustainable levels.

Notwithstanding this advice, concerns about public debt sustainability make a turn to fiscal consolidation quite likely in many countries. Would this turn lead to more inequality in the aftermath of COVID-19?' ${ }^{1}$ We suggest an answer by drawing on evidence from past major epidemics. In Furceri, Loungani, Ostry and Pizzuto, 2020, we discussed why the experience of epidemics over the past two decades is useful to study and showed that these epidemics have led to increases in inequality. Here, we dig deeper by investigating one of the channels through which this could arise, namely the extent of austerity. We exploit differences across epidemics and countries in the extent of fiscal consolidation to investigate whether the rise in inequality is driven by differential moves to austerity. Ours is the first study to provide systematic evidence on this issue to our knowledge.

Section II describes the data on pandemics, inequality and fiscal variables. Section III reviews the evidence on the effects of pandemics prior to COVID-19 and some of the early evidence of the distributional impact of COVID-19. Section IV presents the key results of this paper on the role of fiscal policy in influencing the impact of pandemics on inequality and discusses the policy implications of our results. Concluding remarks are in Section V.

\section{Data Sources}

In this section we describe the data on the major epidemics that are the focus of our paper and the sources of our data on inequality, fiscal balances and government expenditures.

\section{Pandemic events}

As in Ma, Rogers and Zhou (2020) and Furceri et al. (2020), we focus on five major epidemics since 2000: SARS (2003), H1N1 (2009), MERS (2012), Ebola (2014) and Zika (2016). For convenience we refer to these major epidemics as pandemics. The number of countries affected, and statistics on the severity of each event are presented in Table 1. H1N1

\footnotetext{
${ }^{1}$ The word "austerity" - once used mainly by civil society critics of fiscal policies - has gained more common currency, including e.g., in the Financial Times article cited earlier and in academia (see, e.g., Alesina, Favero and Giavazzi, 2020). We use it interchangeably with fiscal consolidation: Ostry, Loungani and Furceri (2016).
} 
(Swine Flu Influenza) was the most widespread with over 6 1/2 million cases across 148 countries (about 1.2 cases per thousand people) and over 19,000 deaths. The other four events affected fewer countries and were largely confined to specific regions-SARS and MERS in Asia, Ebola in Africa, and Zika in the Americas. In terms of mortality rates (deaths/confirmed cases), MERS and Ebola were the most severe, followed by SARS, H1N1 and Zika.

We construct a $(0,1)$ dummy variable, the 'pandemic event,' which takes the value 1 for countries that were declared by the WHO to be affected by a particular pandemic. This gives us a total of 225 pandemic events.

\section{Inequality and fiscal variables}

We use the Gini coefficient as our measure of inequality. The data are from the Standardized World Income Inequality Database (SWIID - version 8.3), which combines information from the United Nations World Income Database (UNWIDER) and the Luxembourg Income Study (LIS). SWIID provides comparable estimates of market (pre-taxes and transfers) and net (post-taxes and transfers) income inequality for 177 countries from 1960 to the present. ${ }^{2}$ We measure redistribution as the difference between the market Gini and the net Gini.

The data on government fiscal balances are from the IMF's World Economic Outlook (WEO) database. The fiscal balance is measured as general government net lending or borrowing (in percent of GDP); it is calculated as revenues minus expenditures, so that positive values indicate surpluses. The WEO database provides internationally comparable fiscal balance data for all the countries for which we have data on the Gini coefficients. ${ }^{3}$

Data on health expenditures (in percent of GDP) are from the World Bank's World Development Indicators. This source provides internationally comparable statistics for current and capital health expenditures for a large number of economies and covers all health spending regardless of the entity or institution that financed and managed that spending. We have date for

\footnotetext{
${ }^{2}$ Solt (2015) and Ostry, Loungani and Berg (2019) discuss the pros and cons of this dataset relative to others.

${ }^{3}$ The fiscal balance variable measures the extent to which general government is either putting financial resources at the disposal of other sectors in the economy and nonresidents (net lending), or utilizing the financial resources generated by other sectors and nonresidents (net borrowing). This balance may be viewed as an indicator of the financial impact of general government activity on the rest of the economy and nonresidents. We use the April 2020 WEO release (https:/www.imf.org/external/pubs/ft/weo/2020/01/weodata/index.aspx).
} 
180 countries from 2000 to the present. ${ }^{4}$ Table 2 provides summary statistics on the variables used in the analysis.

\section{Pandemics And inequality: A Review of The Evidence}

\section{A. Evidence from Historical Pandemics}

In the early months of COVID-19, there was discussion that the pandemic would bring down inequality. This was based partly on the fact that during the intense phases of the initial lockdowns, some low-income workers (such as grocery store workers and some in online retailing) were being offered significant pay increases and being described as heroes, leading to an expectation that they would continue to see improvements in their fortunes. ${ }^{5}$

The narrative that inequality might decline was shaped by evidence that it had done so in the aftermath of historical pandemics such as the Black Death (Scheidel, 2017; Milanovic, 2016). Dosi, Fanti, Virgillito (2020), however, challenged this narrative, pointing out that COVID-19 is not expected to have mortality rates of "the magnitude recalling the Black Death or even the Spanish Flu" and thus the adverse impact on labor supply would be lower. They conjectured that the COVID-19 "unlike other historical episodes such as the Plague of the 14th century, will not serve to alleviate income and wealth inequalities."

Alfani (2020a, 2020b) notes that while the impact on labor supply is an important determinant of the distributional impacts of pandemics, other institutional characteristics — such as the steps that the rich are able to take to protect themselves and the conditions of the working poor at the time of the pandemics — also play a role. The Black Death killed "about half the population" of Europe and the Mediterranean, and the resulting scarcity of labor allowed real wages to rise and "the poorest strata enjoyed a boost to their bargaining power and were able to negotiate better conditions." However, $17^{\text {th }}$ century plagues, though they had severe mortality rates approaching the magnitude of the Black Death, did not lead to egalitarian outcomes; this

\footnotetext{
${ }^{4}$ Current health expenditures include healthcare goods and services consumed during each year. Capital health expenditures include health infrastructure (buildings, machinery, IT) and stocks of vaccines for emergency or outbreaks. See https://datacatalog.worldbank.org/dataset/world-development-indicators for details.

${ }^{5}$ See, for instance, some of the views discussed in "How the Coronavirus Might Reduce Income Inequality," Wall Street Journal (April 19, 2020); despite the headline, however, the article noted that the "Black Death and other pandemics pushed wages higher, but the impact will likely be different this time."
} 
occurred in part because the rich, recognizing that plagues were to be a recurrent scourge, had taken steps to protect their wealth and property by using new mechanisms such as the entail. Recurrent plagues in the $19^{\text {th }}$ century caused by the spread of cholera had devastating impacts on the poor as they lived in "unhealthy and crowded living conditions," with reductions in inequality arising only in cases where the resulting mortality rates were so high that they essentially led to "the extermination of the poor" (Alfani, 2020a).

Evidence also suggests that the 1918 Spanish Flu had adverse distributional consequences. Though deaths were high in absolute numbers, they represented about $2 \%$ of the world's labor force, with Italy reporting one of the highest mortality rates in Europe. Galletta and Giommoni (2020) found that income inequality rose in Italian towns more affected by the pandemic, driven by a significant reduction in incomes of those at the bottom of the income distribution while there was "no impact" on incomes at the top.

\section{B. Evidence from $21^{\text {st }}$ century pandemics}

To estimate the distributional impact of pandemics over the last two decades, Furceri, Loungani, Ostry and Pizzuto (2020) follow the method proposed by Jordà (2005) and estimate impulse response functions directly from local projections:

$$
y_{i, t+k}=\alpha_{i}^{k}+\gamma_{t}^{k}+\beta^{k} D_{i, t}+\theta^{k} X_{i, t}+\varepsilon_{i, t+k}(1)
$$

where $y_{i, t}$ is the market or net Gini coefficient, or redistribution, for country $i$ in year $t$; $\alpha_{i}$ are country fixed effects, included to take account of differences in countries' average income distribution; $\gamma_{t}$ are time fixed effects, included to take account of global shocks such as shifts in oil prices or the global business cycle; $D_{i, t}$ is a dummy variable indicating a pandemic event that affects country $i$ in year $t . X_{i, t}$ is a vector of controls that includes four lags of the dependent variable and the pandemic dummy as well as country-specific time trends. ${ }^{6}$ Equation (1) is estimated for each horizon (year) $k=0, . ., 5$. Impulse response functions are computed using the estimated coefficients $\beta^{k}$, and the associated confidence bands are obtained using the

\footnotetext{
${ }^{6}$ In the models for net or market Gini or redistribution, we include four lags of both net and market Gini.
} 
estimated standard errors of the coefficients $\beta^{k}$ based on robust standard errors clustered at the country level.

Figure 2 shows the results on the impact of pandemics on inequality over the last two decades based on estimates of equation (1). Both market and net Gini increase following a pandemic. The increase is about 0.3 after three years and is both statistically and economically significant given that Gini coefficients change slowly over time. ${ }^{7}$ The extent of redistribution goes up for the first two years following the start of the pandemic but then declines back toward zero; however these effects are not statistically significant.

As shown in previous work (Furceri et al., 2020) these findings are robust to several checks. These include using alternative regression strategies such as the autoregressive distributed lag model (ADL) used in in Romer and Romer (2010) and Furceri, Loungani and Ostry (2019); an instrumental variable (IV) approach; and the augmented inverse probability weighting (AIPW) estimation as in Jordà and Taylor (2016). ${ }^{8}$ The results are also broadly unchanged when we include several control variables in the regression-such as proxies for the level of economic development, demographics, measures of trade and financial globalizationand when we use a continuous variable to measure the intensity of pandemics instead of a $(0,1)$ indicator. Finally, the results are also robust to changes in the sample period, to the use of other measures of inequality, and to placebo tests.

\section{Distributional impacts of COVID-19: Early evidence}

While it is too early to tell what impact COVID-19 will ultimately end up having on inequality, the indications thus far are that many of the channels that raise inequality over time are already operative. First, evidence from the early months of the pandemic from areas which were hit hard suggests that the poor have been more prone to getting infected. In New York City, for instance, people in rich zip codes were far less likely to test positive than those in poorer zip codes (Schmitt-Grohe et al., 2020). Brown and Ravallion (2020) found that infection rates were

\footnotetext{
${ }^{7}$ The effects on the Gini tend to level off past five years.

${ }^{8}$ The baseline local projection results are also robust to the Teulings and Zubanov (2014) bias correction.
} 
higher in U.S. counties with a higher share of African Americans and Hispanics and with higher income inequality. ${ }^{9}$

Second, the poor have also been more likely to die if they get infected, which is likely to exacerbate the economic strains on their households in the coming years. In the United States, mortality rates are higher among low-income people and among minorities: African Americans account for $25 \%$ of deaths from COVID-19 in the US though they make up a little under $13 \%$ of the US population.

Third, poorer people are in jobs where working from home is less likely to be an option; by some estimates, the poorest $20 \%$ of the population are in jobs that can be done from home in less than $20 \%$ of cases (Avdiu and Nair 2020). In Italy, workers with low educational attainment and low-income service workers were more likely to have stopped working in the weeks following the lockdown and suffered an immediate fall in incomes; relaxations of some of the lockdown restrictions benefitted mostly highly educated workers and white-collar workers (Galasso, 2020). Survey data from Japan on COVID-19's effects finds that low-skilled and contingent workers suffered more than highly skilled and regular workers (Kikuchi et al., 2020). ${ }^{10}$

Fourth, in addition to these immediate effects, there are indirect and longer-lasting effects from job loss and other shocks to income. Nearly $40 \%$ of the global workforce is estimated to be employed in sectors that face high risk of worker displacement, with a high proportion of workers in informal employment and limited access to health services and social protection (ILO 2020). Such workers are at high risk on not regaining their livelihoods even after economies start to recover. In many countries, low-income households can also suffer an impact on non-labor income due to decline in remittances as the pandemic affects the livelihoods of migrants. Global remittance flows, which fell 5\% during the 2009 financial crisis, are expected to fall $20 \%$ in 2020, the sharpest decline since 1980 (World Bank, 2020).

\footnotetext{
${ }^{9}$ See Coibion, Gorodnichenko and Weber (2020) and Chen and Krieger (2020) for further evidence on the distributional impacts of COVID-19 on U.S. labor markets.

${ }^{10}$ See also Cugat and Narita (2020) for simulation-based estimates of the likely impact of COVID-19 on the Gini coefficient when low-income workers are less able to work from home than higher-income workers. One other channel for long-lasting distributional impacts of COVID-19 could be through education: children of wealthy families may get better quality home schooling than those from poorer families.
} 
Indeed, the fear of increasing inequality due to the COVID-19 pandemic is also confirmed by preliminary results from studies using real-time data. For example, using data from a large-scale survey of U.K. households, Crossley, Fisher and Low (2020) show that people in the lowest quintiles of income and those from minority ethnic groups have experienced the worst labor market shocks. Similarly, using transaction data from a large Fintech company, Hacioglu, Känzig and Surico (2020) and Surico, Känzig and Hacioglu (2020) document a surge in market income inequality in the United Kingdom since the beginning of the COVID-19 crisis. Similar findings are those suggested by Aspachs et al. (2020) for Spain. Using high frequency data on bank records, wages and public transfers, they provide evidence of increasing wage inequality "mainly due to job losses and wage cuts for low-income workers". The impact of the pandemic shock is not limited to income-related losses: Blundell et al. (2020) document the very heterogeneous impact of COVID-19 across society, creating new and reinforcing old inequalities on health, education, labor market access and other socio-demographic indicators.

\section{PAndemics And Inequality: Role of the Fiscal ResPonse}

\section{A. Pandemics, Inequality and Austerity}

We now turn to the role that countries' fiscal response plays in influencing the impact of pandemics on inequality. We begin by estimating the average response of government fiscal policies following a pandemic. We use equation (1), with either the government fiscal balance or government health expenditures as the dependent variable.

Figure 3 shows the average response of the fiscal balance following a pandemic. As expected, the fiscal balance weakens reflecting both increased expenditures and falling revenues. Five years after the start of the pandemic, the fiscal balance (as a percent of GDP) is about $2 \frac{1}{2}$ percentage points lower than at the outset.

Government total health expenditures increase for four years after the start of a pandemic before returning to normal, as shown in the left panel of Figure 4 . The peak increase is about 0.3 percentage points of GDP, and reflects an increase in current health expenditures, while the increase in capital health expenditures is not statistically significant.

The fiscal response varies considerably across pandemic events. We exploit this variation to see whether the impact on inequality is different in episodes characterized by strong austerity 
compared with other episodes. Specifically, we modify equation (1) to allow for the response of inequality to vary with country characteristics:

$y_{i, t+k}=\alpha_{i}^{k}+\gamma_{t}^{k}+F\left(z_{i t}\right)\left[\beta_{L}^{k} D_{i, t}\right]+\left(1-F\left(z_{i t}\right)\right)\left[\beta_{H}^{k} D_{i, t}\right]+\theta_{L}^{k} X_{i, t}+\varepsilon_{i, t+k}$

with $F\left(z_{i t}\right)=\frac{e x p^{-\gamma z_{i t}}}{1+\left(e_{x p^{-\gamma z}}\right)}, \quad \gamma=1.5$

where $\mathrm{z}$ is an indicator of the country's response to the pandemic (which is either the degree of redistribution or government's fiscal balance or health expenditures) normalized to have zero mean and a unit variance.

The weights assigned to each regime vary between 0 and 1 according to the weighting function $F($.$) , so that F\left(z_{i t}\right)$ can be interpreted as the probability of being in a given state. The coefficients $\beta_{L}^{k}$ and $\beta_{H}^{k}$ capture the distributional impact of a pandemic event at each horizon $k$ in cases of strong response $\left(F\left(z_{i t}\right) \approx 1\right.$ when $z$ goes to minus infinity) and mild response (1 $F\left(z_{i t}\right) \approx 1$ when $\mathrm{z}$ goes to plus infinity), respectively. $F\left(z_{i t}\right)=0.5$ is the cutoff between low and high country-specific characteristics - that is, for example, low and high health expenditures. We estimate equation (2), segmenting episodes into: (i) low vs. high redistribution; (ii) mild vs. strong response of the fiscal balance (i.e. surpluses or small deficits vs. larger deficits); and (iii) small vs. large response of health expenditures.

In order to isolate discretionary spending shocks from automatic changes driven by business cycle fluctuations, we follow an approach inspired by Perotti (1999). Specifically, discretionary shocks are identified as innovations to economic activity, that is as the residuals from the following regression:

$s_{i t}=\alpha_{i}+\beta_{i} \Delta y_{i t}+\varepsilon_{i t}$,

in which $s$ denotes the fiscal balance (or health expenditures) as percent of GDP; $\Delta y$ is GDP growth; and $\alpha_{i}$ are country fixed effects.

The results from estimating equation (2) are shown in Figure 5. The key finding is that, regardless of the measure of austerity, its impact is to raise inequality in the aftermath of pandemics. This is shown in the left-hand side panels in the three cases. In sharp contrast, when 
the fiscal response is strongly supportive, inequality barely increases as shown in the right-hand side panels; again, this holds for all three measures of the fiscal response. Moreover, in the cases of austerity, the impact on the net Gini is roughly similar for all three measures and quantitatively large - five years on, the Gini increases by about 0.6 points, twice the average impact shown earlier in Figure 2.

\section{B. Policy implications}

As discussed above, developments since the start of COVID-19 appear similar to that in the first year of previous pandemics in that there are indications of increases in inequality. The results just presented suggest, however, that the increase in inequality is not inevitable and can be held in check by a strong supportive fiscal response. The question is whether it would be prudent to do so given the high level of debt-to-GDP in many advanced and emerging economies and the risk of debt distress already in half of low-income economies.

Two arguments are usually made in support of paying down the debt aggressively, even in countries with sufficient fiscal space. The first is that strong progress in paying down the debt puts countries at reduced risk of a financial crisis in the eyes of financial markets. However, markets generally attach low probabilities of a debt crisis to countries with a strong record of being fiscally responsible (Mendoza and Ostry, 2007), which gives them latitude to run deficits even when the debt level is high (Ostry and others, 2010; Ghosh and others, 2013). Such countries gain little from debt reduction in terms of insurance against a future fiscal crisis; for example, moving from a debt ratio of 120 percent of GDP to 100 percent of GDP over a few years yields only a small reduction in crisis risk (Baldacci and others, 2011). Set against the small insurance benefit, the costs of the tax increases or expenditure cuts required to bring down the debt can be much larger (Ostry, Ghosh, and Espinoza, 2015).

The second argument is that fiscal consolidations can be expansionary (that is, raise output and employment), in part by raising private sector confidence and investment. Expansionary austerity is, however, a rare occurrence. Typically, episodes of fiscal consolidation have been followed by drops rather than by expansions in output (Jordà and Taylor, 2016). On average, a consolidation of 1 percent of GDP increases the long-term unemployment rate by 0.6 
percentage point and raises the Gini coefficient by 1.5 percent within five years (Ball and others, 2013; Ostry, Loungani and Berg, 2019).

Hence, while country circumstances of course differ considerably, a case can be made that there is still room for strong fiscal support in many economies (Hughes, 2020; IMF, 2020). Central banks in several advanced economies and emerging market and middle-income economies can continue to facilitate the fiscal response by directly or indirectly financing some part of the debt buildup. The likelihood that low long-term interest rates will persist moderates debt-service burdens and can also allow governments to continue to extend the maturity of government bonds. ${ }^{11}$ In low-income developing countries, these policy options are much less readily available, and the alleviation of financing constraints could require greater assistance from private sector creditors and additional concessional financing from the official sector (IMF, 2020). Absent such support, there is fear of a lost decade of growth, particularly in developing countries (UNCTAD, 2020). ${ }^{12}$

The experience following the Global Financial Crisis offers a cautionary tale of the dangers of premature fiscal consolidation. In 2010, buoyed by what turned out to be mistaken signs of a strong recovery, many advanced economies signaled a U-turn in their fiscal stance, a policy choice that many regard as partly responsible for the tepid recovery that followed and the consequent failure to bring about reductions in the debt-to-GDP ratios (Stiglitz, 2012; IEO 2014; Dosi et al., 2016). ${ }^{13}$ The turn to austerity may also have had impact on governments' health expenditures in the run-up to the COVID-19 pandemic (Soener, 2020). For instance, looking at

\footnotetext{
${ }^{11}$ The state of the debate in Canada is summed up in the Globe and Mail (July 24, 2020), which argues: “... there will be growing calls for a future of smaller government and less spending ... If that's the way post-2020 Canada goes, because Canadians think they have no other options, it will be a missed opportunity, and a great mistake. The country cannot borrow unlimited amounts, but current debts are more than manageable ... Ottawa can borrow for 30 years at less than 1 per cent, so $\$ 100$-billion in debt costs just \$1-billion a year to service."

${ }^{12}$ In its 2020 Trade and Development Report, UNCTAD states that its "model simulations indicate that an early return of austerity would set off a vicious circle of low employment generation, wage stagnation, slower economic growth and higher pressure on government budgets. In particular, a return to pre-pandemic austerity will reduce annual global growth by 1 percentage point and increase the global unemployment rate by 2 percentage points until 2030. Labor income shares will also decrease, by more than 3 percentage points globally, implying a transfer of income from workers to profit earners of approximately $\$ 40$ trillion by 2030 ."

${ }^{13}$ Some have noted that the IMF's current advice on fiscal consolidation "is a reversal of the message given a decade ago at the equivalent stage in the financial crisis" and that the IMF's Independent Evaluation Office (IEO) had "subsequently assessed that [the IMF] had been too quick to advocate austerity in 2010-11" (Financial Times, 2020). However, some in civil society remain skeptical of the IMF's turnaround, arguing that country-level advice remains supportive of austerity (see, e.g., Oxfam, 2020).
} 
the European experience, a study sponsored by the WHO found that European countries had cut health budgets and a majority of countries reduced investment in hospitals after 2010, with marked declines in countries such as Spain and Italy (Thomson, 2020); an OECD study found that "reducing wages in public hospitals, postponing staff replacement and delaying investment in hospital infrastructure were among the most frequent measures taken in EU countries to balance health budgets" (OECD, 2016). To summarize, there appears to be a case that governments should try to maintain fiscal support until economic recovery is assured and some evidence from the experience following the Global Financial Crisis of the risks of a premature U-turn in fiscal stances.

At the same time, it is worth noting that there are already some examples of the potency of fiscal policies in reversing some of the increases in inequality arising thus far during the COVID-19 pandemic (e.g., Surico, Känzig and Hacioglu (2020) for the case of the United Kingdom). Aspachs et al. (2020) document how public transfers were very effective in offsetting most, though not all, of the increase in wage inequality in the early months of the COVID-19 crisis. They concluded that their evidence is both reassuring of how quickly governments can act - particularly given that transfers can be targeted and quickly be sent electronically to recipients' bank accounts - but also raised concerns about "how things might evolve should the intensity of government intervention decline due to budgetary reasons." Likewise, Balasubramanian et al. (2021) discuss the effectiveness of electronic direct benefit transfers in protecting many vulnerable segments of the population in India from the effects of COVID-19, though there are concerns that many informal workers in India and elsewhere may fall outside these electronic social safety nets (Furceri et al., 2020).

Instead of a premature return to austerity, countries would do better by: (i) anchoring their fiscal plans in a credible medium-term framework and (ii) orienting public expenditures over the coming years toward productive investments in digital and green infrastructure (Gaspar 2020). By building market confidence in fiscal sustainability and boosting growth, respectively, these two steps can bring down the debt-to-GDP ratio over time in a more durable way than 
sharp fiscal consolidations, which risk causing such an immediate fall in output and keeping the debt-to-GDP ratio unchanged or even raising it. ${ }^{14}$

\section{Conclusions}

This paper provides novel evidence that the rise in inequality in the aftermath of major epidemics over the last two decades has been higher in episodes of greater austerity. Specifically, the increase in the Gini coefficient is nearly thrice as large in episodes of higher government fiscal balance (i.e. smaller fiscal deficits), lower government health expenditures, and lower redistribution than in cases where there was no turn to austerity. It would be useful in future work to consider in greater detail whether the composition of fiscal consolidation (spending cuts vs. tax increases) matters for the distributional impacts and how the impacts differ across country groups (advanced vs. emerging markets and low-income countries).

The descriptive evidence summarized in this paper on the distributional effects on COVID-19 suggests that it is likely to lead to an increase an inequality in the absence of policy actions, including fiscal and monetary policies, that are more supportive than in the past. However, many advanced economies are at historically high debt-to-GDP ratios and half of lowincome economies are at or near severe risk of debt distress. In such a situation, is a turn to austerity the prudent course of action, despite the likely impact on inequality? Many observers, including the IMF, urge caution:

"Exceptional fiscal and monetary measures have gone a long way toward helping people and businesses survive the pandemic ...Going forward, it will be critical for countries not to withdraw support prematurely, and importantly, to continue to target the measures in a way that helps the most vulnerable." (Georgieva, 2020).

We summarize the arguments in favor of this position, noting the fiscal space that many countries, particularly in advanced economies and large emerging markets, still have in an environment of low interest rates and with possibility of some further support from central banks. In low-income countries, maintaining debt sustainability is likely to require further

\footnotetext{
${ }^{14}$ See, for example, Sandbu (2020a), “UK needs more fiscal planning in a pandemic, not less," Sandbu (2020b) reiterates that it "was wrong to drop a full-fledged, multiyear spending review because of the uncertain outlook. More detailed, longer-term spending commitments are a way to provide certainty to the private sector and encourage the spending and investment on which a speedy recovery — and hence better public finances — rely." See also Hutchison (2020).
} 
support from private creditors (as noted, for example in the G20 Leaders Declaration, November 21, 2020).

Maintaining fiscal support is particularly important in checking the rise of excessive inequality since many other factors, such as increased automation in the aftermath of the pandemic, are likely to push in the direction of increasing inequality (Loungani and Ostry, 2020; Qureshi, 2020). The descriptive evidence thus far suggests that the channels that likely led to the increases in inequality after five major pandemics of the last two decades have continued to operate following COVID-19. However, there are examples that fiscal policy remains potent in checking these adverse distributional impacts, particularly with the possibility of quick action through various kinds of electronic transfers, if countries can summon up the political will to do so. 


\section{References}

Alesina, A., Favero, C., \& Giavazzi, F. (2020). Austerity: When it Works and When it Doesn't. Princeton University Press.

Alfani, G. (2020a), "Pandemics and Inequality: A Historical Overview," VoxEU, October 15. Alfani, G. (2020b), "Epidemics, Inequality, and Poverty in Preindustrial and Early Industrial Time", Journal of Economic Literature (forthcoming).

Aspachs, O., R. Durante, J. García Montalvo, A. Graziano, J. Mestres and M. Reynal-Querol (2020), "Real-Time Inequality and the Welfare State in Motion: Evidence from COVID-19 in Spain", CEPR Discussion Paper n. 15118.

Avdiu, B. and G. Nayyar (2020), "When face-to-face interactions become an occupational hazard: Jobs in the time of COVID-19, ” Brookings Review, March 30.

Baldacci, E., I. Petrova, N. Belhocine, G. Dobrescu, and S. Mazraani (2011), "Assessing Fiscal Stress," IMF Working Paper 11/100 (Washington: International Monetary Fund).

Balasubramanian, S., R. Kumar and P. Loungani (2021), "Locational Determinants of Inequality in India," IMF Working Paper No. 21/50.

Ball, L., D. Furceri, D. Leigh, and P. Loungani (2013), "The Distributional Effects of Fiscal Austerity," UN-DESA Working Paper 129 (New York: United Nations).

Blundell, R., Costa Dias, M., Joyce, R., \& Xu, X. (2020). COVID-19 and Inequalities. Fiscal Studies, 41(2), 291-319.

Brown, C. and M. Ravallion (2020), "Inequality and the coronavirus: Socioeconomic covariates of behavioral responses and viral outcomes across US counties', NBER Working Paper 27549.

Chen, J. and N. Krieger (2020), "Revealing the unequal burden of COVID-19 by income, race/ethnicity, and household crowding: US county vs ZIP code analyses", Harvard Center for Population and Development Studies Working Paper Volume 19, No. 1.

Coibion, O., Y. Gorodnichenko and M. Weber (2020), "Labour markets during the COVID-19 crisis: A preliminary view", NBER Working Paper No. 27017

Crossley, T. F., Fisher, P., \& Low, H. (2020), “The Heterogeneous and Regressive Consequences of COVID-19: Evidence from High Quality Panel Data," Journal of Public Economics. 104334.

Cugat, G. and F. Narita (2020), "How COVID-19 Will Increase Inequality in Emerging Markets and Developing Economies," IMF Blog, Oct. 29.

Dosi, G.; A. Napoletano, A. Roventini and T. Treibich (2014), "The short- and long-run damages of fiscal austerity: Keynes beyond Schumpeter," LEM Working Paper Series, No. 2014/22, Scuola Superiore Sant'Anna, Laboratory of Economics and Management, Pisa.

Dosi, G., L. Fanti, and M. Virgillito (2020), "Unequal societies in usual times, unjust societies in pandemic ones," LEM Working Paper Series, No. 2020/14, Scuola Superiore Sant'Anna, Laboratory of Economics and Management, Pisa.

Financial Times (2020), "IMF says austerity is not inevitable to ease pandemic impact on public finances," October 14.

Furceri, D., P. Loungani and J.D. Ostry (2019), "The Aggregate and Distributional Effects of Financial Globalization: Evidence from Macro and Sectoral Data". Journal of Money, Credit and Banking, 51, 163-198.

Furceri, D., P. Loungani, J. D. Ostry and P. Pizzuto (2020), "Will COVID-19 affect inequality? Evidence from past pandemics", COVID Economics: 138-157. 
G20 (2020), Leaders' Declaration, Nov. 21.

Galasso, V (2020), "COVID: Not a great equaliser", COVID Economics: 19.

Galletta, S, and T Giommoni (2020), "The effect of the 1918 influenza pandemic on income inequality: Evidence from Italy", COVID Economics: 33.

Georgieva, K. (2020), Remarks at the IMF-University of Tokyo Conference on Lessons from the Global Financial Crisis in The Age of COVID-19, November 23.

Ghosh, A. J. Kim, E. Mendoza, J. D. Ostry, and M. Qureshi (2013), "Fiscal Fatigue, Fiscal Space and Debt Sustainability in Advanced Economies," Economic Journal, Vol. 123, No. 566, pp. F4-F30.

Globe and Mail (2020), “Austerity wasn't the right path before the pandemic, and it can't be the road chosen after it," Editorial, July 24.

Hacioglu, S., Känzig, D., \& Surico, P. (2020), "The distributional impact of the pandemic," CEPR Discussion Paper, DP15101.

Hughes, R. (2020), “Safeguarding governments' financial health during coronavirus: What can policymakers learn from past viral outbreaks?", Resolution Foundation, March.

Hutchison, M. (2020), “The Global Pandemic, Policy Space and Fiscal Rules to Achieve Stronger Stabilization Policies," Seoul Journal of Economics, Vol. 33, No. 3.

IEO (2014), Response to the Financial and Economic Crisis. International Monetary Fund.

ILO, (2020), ILO Monitor 2nd edition: COVID-19 and the world of work.

IMF (2020), Fiscal Monitor, October.

Jordà, O. (2005), "Estimation and inference of impulse responses by local projections," American Economic Review 95: 161-182.

Jordà, Ò., \& A. Taylor, A. (2016), "The time for austerity: estimating the average treatment effect of fiscal policy," The Economic Journal, 126(590), 219-255.

Jordà, O., S. Singh and A. Taylor (2020), "Pandemics: Long-Run Effects" Covid Economics 1: $1-15$.

Kikuchi, S, S Kitao and M Mikoshiba (2020), "Heterogeneous employment vulnerability and inequality in Japan," VoxEU.org, May 3

Loungani, P. and J. D. Ostry, 2020, "Will COVID-19 Raise Inequality? Evidence from Past Epidemics and Crises," Presentation at Institute for International Economic Policy, George Washington University, May 26.

Ma, C., J. Rogers and S. Zhou (2020), "Global Financial Effects”, Covid Economics 5: 56-78.

Mendoza, E. and J. D. Ostry (2007), "International Evidence on Fiscal Solvency: Is Fiscal Policy 'Responsible'?' Journal of Monetary Economics, Vol. 55, No. 6, pp. 1081-93.

Milanovic, B. (2016). Global inequality: A new approach for the age of globalization. Harvard University Press.

OECD, 2016, Health at a Glance: Europe 2016.

Ostry, Jonathan D., Atish R. Ghosh, Jun I. Kim, and Mahvash Qureshi, 2010, "Fiscal Space," IMF Staff Position Note 10/11 (Washington: International Monetary Fund).

Ostry, Jonathan D., Atish R. Ghosh, and Raphael Espinoza, 2015, "When Should Public Debt Be Reduced?" IMF Staff Discussion Note 15/10 (Washington: International Monetary Fund).

Ostry, Jonathan D., Prakash Loungani, and Davide Furceri, 2016, "Neoliberalism: Oversold?" Finance and Development, Volume 53, No. 2 (June), pp. 38-41.

Ostry, J. D., Loungani, P., \& Berg, A. (2019), Confronting Inequality: How Societies Can Choose Inclusive Growth, Columbia University Press.

Oxfam (2020), "IMF paves way for new era of austerity post-COVID-19," October 12. 
Perotti, R. (1999). "Fiscal Policy in Good Times and Bad." Quarterly Journal of Economics 114 (4): 1399-436.

Qureshi, Z. (2020), “Tackling the inequality pandemic: Is there a cure?”, Brookings Report, Nov. 17.

Romer, C. and D. Romer (2010), "The Macroeconomic Effects of Tax Changes: Estimates Based on a New Measure of Fiscal Shocks." American Economic Review, 100(3), 763-801.

Sandbu, M. (2020a), "UK needs more fiscal planning in a pandemic, not less," Financial Times, October 25.

Sandbu, M. (2020b), "There is no fiscal emergency," Financial Times, Nov. 26.

Schmitt-Grohé, S., K. Teoh and M. Uribe (2020), "COVID-19: Testing Inequality in New York City", Covid Economics 8: 27-43.

Scheidel, W. (2017), The Great Leveler: Violence and the History of Inequality from the Stone Age to the Twenty-First Century, Princeton: Princeton University Press.

Soener, M. (2020), "How Austerity is Worsening Coronavirus," Books \& Ideas, College de France, June 4.

Stiglitz, J. (2012), "After Austerity,” Project Syndicate, May 7.

Stiglitz, J. (2020), "Conquering the Great Divide," Finance \& Development, Fall 2020.

Solt, F. (2015), "On the assessment and use of cross-national income inequality datasets. The Journal of Economic Inequality," 13(4), 683-691.

Surico, P., D. Känzig and S. Hacioglu (2020). "Consumption in the time of COVID-19: Evidence from UK transaction data" CEPR Discussion Paper, DP14733.

Teulings, C. and N. Zubanov (2014), "Is Economic Recovery a Myth: Robust Estimation of Impulse Responses," Journal of Applied Econometrics, 29(3), 497-514.

Thomson, S. and others. "Economic Crisis, Health Systems and Health in Europe: Impact and Implications for Policy," WHO, 2015.

UNCTAD (2020), Trade and Development Report.

Wall Street Journal (2020), "How the Coronavirus Might Reduce Income Inequality," April 19. World Bank (2020), "Poverty and Distributional Impacts of COVID-19: Potential Channels of Impact and Mitigating Policies", Brief, April 16. 
Figure 1. PANDEMIC CASES BY REGION
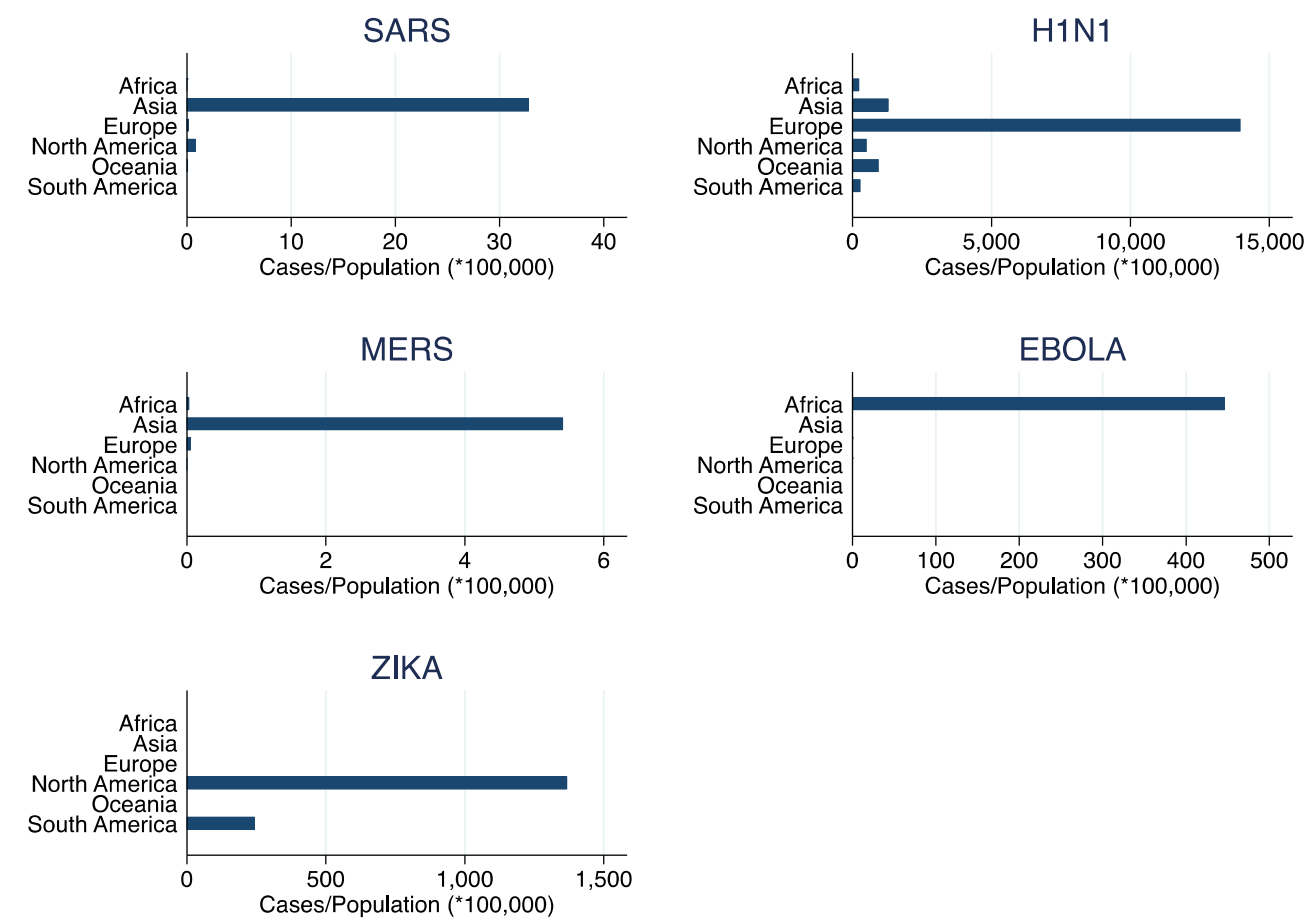

Sources: See notes for Table 1. 
FIGURE 2. IMPACT OF PANDEMICS ON MARKET AND NET GINI AND REDISTRIBUTION
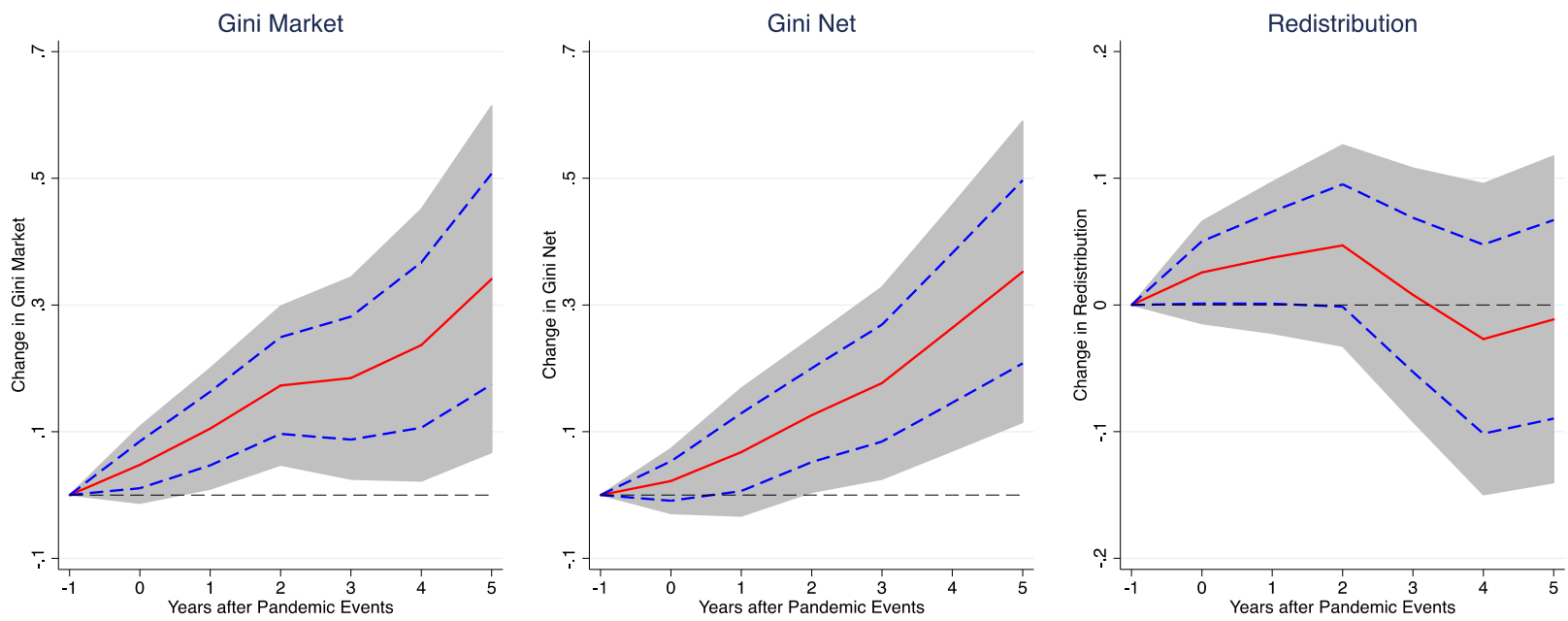

Notes: Impulse response functions are estimated using a sample of 177 countries over 1960-2019. The graph shows the response and 90 percent confidence bands. The x-axis shows years $(k)$ after pandemic events; $\mathrm{t}=0$ is the year of the pandemic event. Estimates based on $y_{i, t+k}=\alpha_{i}^{k}+\gamma_{t}^{k}+\beta^{k} D_{i, t}+\theta^{k} X_{i, t}+\varepsilon_{i, t+k} . y_{i, t}$ is the Gini coefficient (or level of redistribution) for country $i$ in year $t ; \alpha_{i}$ are country fixed effects; $\gamma_{t}$ are time effects; $D_{i, t}$ is a dummy variable indicating a pandemic event that affects country $i$ in year $t . X_{i, t}$ is a vector that includes four lags of net and market Gini, four lags of the pandemic dummy a as well as country-specific time trends. 
FIGURE 3. IMPACT OF PANDEMICS ON GENERAL GOVERNMENT FISCAL BALANCE

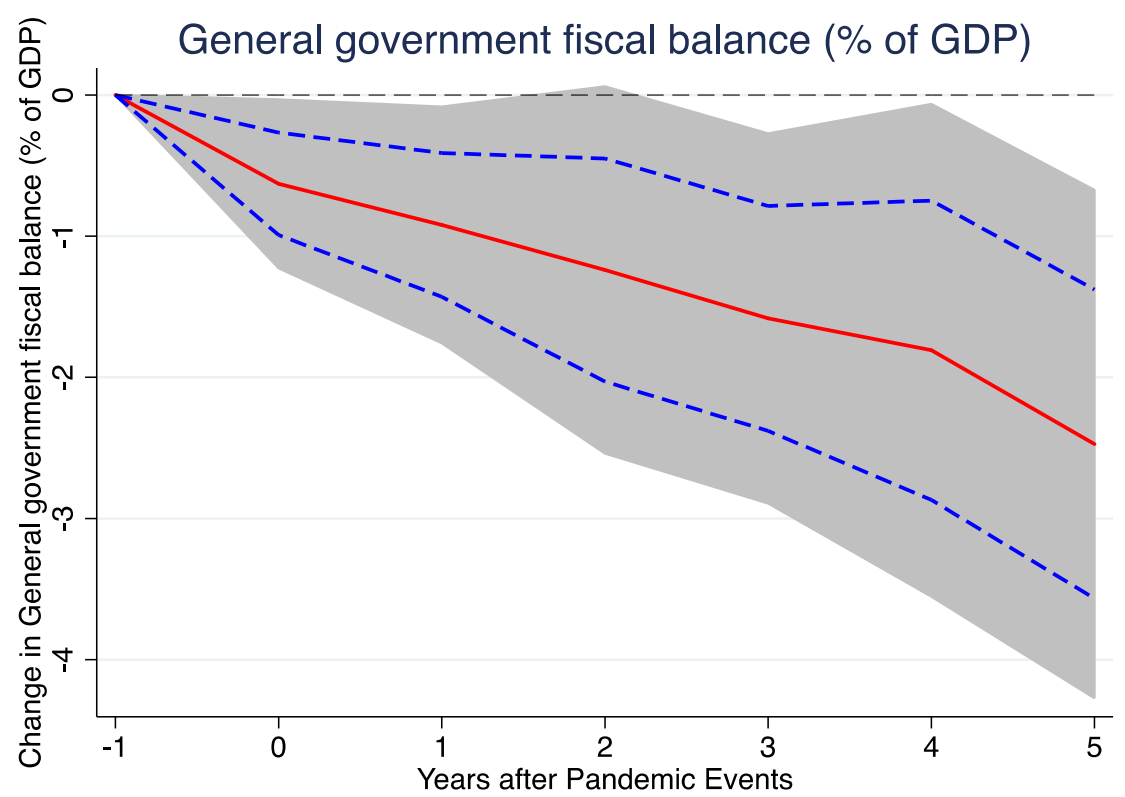

Notes: Impulse response functions are estimated using a sample of 185 countries over 1980-2019. The graph shows the response and 90 percent confidence bands. The $\mathrm{x}$-axis shows years $(k)$ after pandemic events; $\mathrm{t}=0$ is the year of the pandemic event. Estimates are based on $y_{i, t+k}=\alpha_{i}^{k}+\gamma_{t}^{k}+\beta^{k} D_{i, t}+\theta^{k} X_{i, t}+\varepsilon_{i, t+k} \cdot y_{i, t}$ is the general government fiscal balance for country $i$ in year $t ; \alpha_{i}$ are country fixed effects; $\gamma_{t}$ are time fixed effects; $D_{i, t}$ is a dummy variable indicating a pandemic event that affects country $i$ in year $t . X_{i, t}$ is a vector that includes four lags of the dependent variable, four lags of the pandemic dummy and country-specific time trends. 
FigURE 4. IMPACT OF PANDEMICS ON HEALTH EXPENDITURES
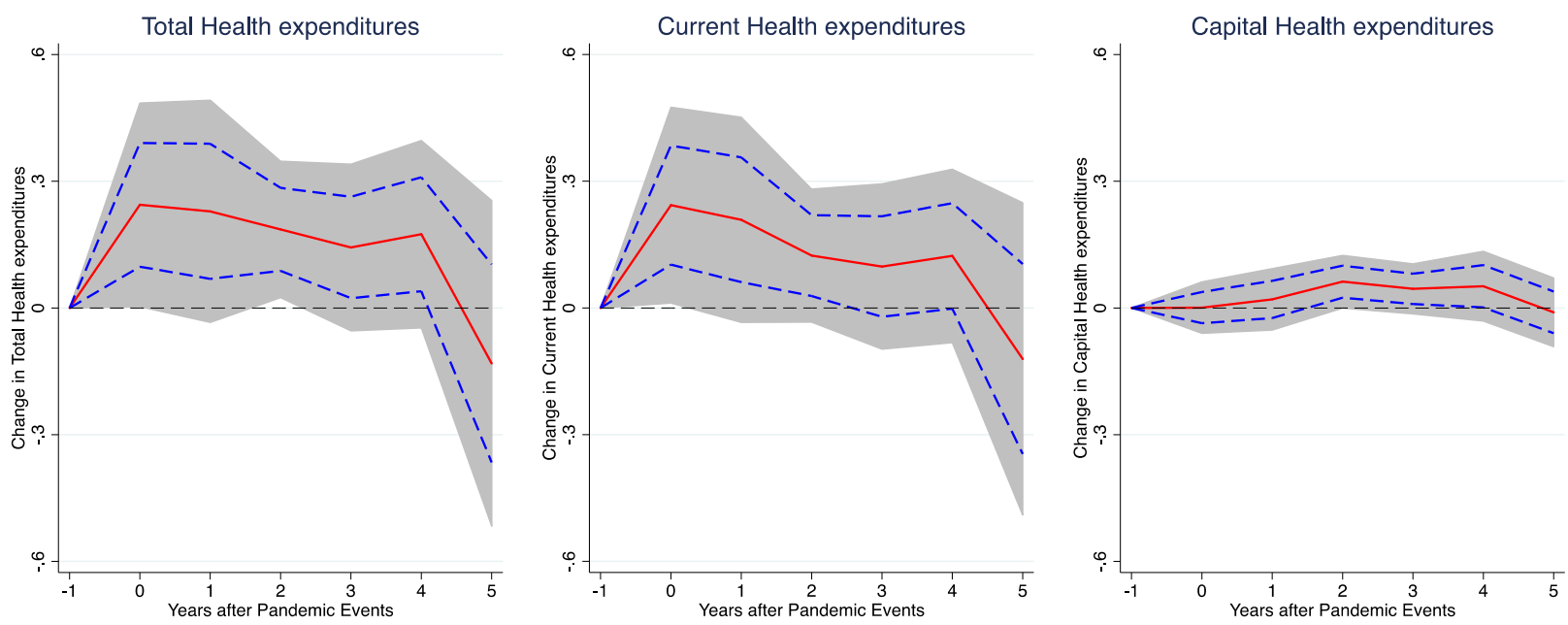

Notes: Impulse response functions are estimated using a sample of 180countries over 2000-2017. The graph shows the response and 90 percent confidence bands. The x-axis shows years $(k)$ after pandemic events; $\mathrm{t}=0$ is the year of the pandemic event. Estimates based on $y_{i, t+k}=\alpha_{i}^{k}+\gamma_{t}^{k}+\beta^{k} D_{i, t}+\theta^{k} X_{i, t}+\varepsilon_{i, t+k} \cdot y_{i, t}$ is the level of Health Expenditures (as \% of GDP) for country $i$ in year $t ; \alpha_{i}$ are country fixed effects; $\gamma_{t}$ are time fixed effects; $D_{i, t}$ is a dummy variable indicating a pandemic event that affects country $i$ in year $t . X_{i, t}$ is a vector that includes four lags of the dependent variable, four lags of the pandemic dummy and country-specific time trends. 
FigURE 5. IMPACT OF PANDEMICS ON NET GINI: THE ROLE OF THE FISCAL RESPONSE
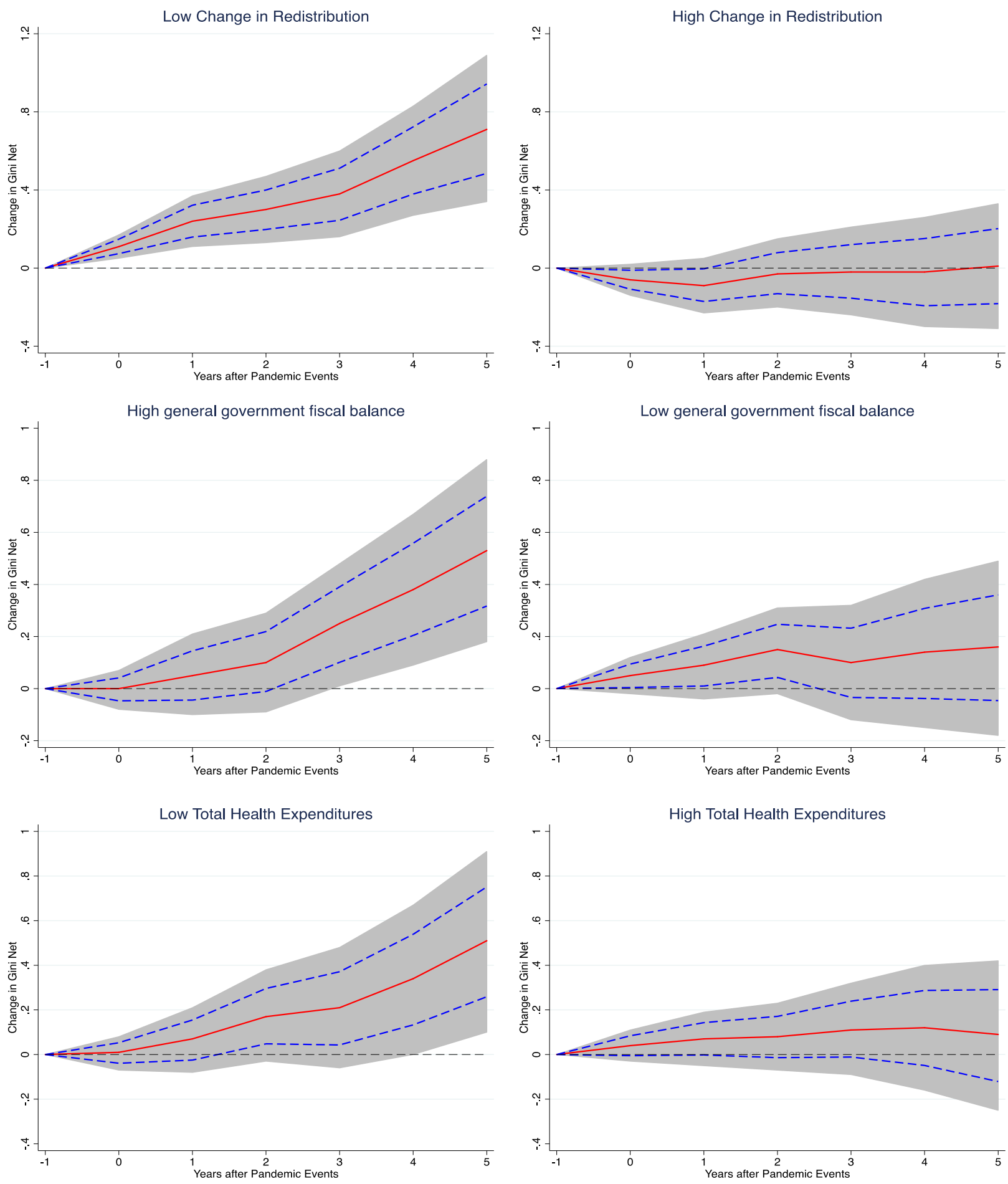

Notes: The graph shows the response and 90 percent confidence bands. The $\mathrm{x}$-axis shows years $(k)$ after pandemic events; $\mathrm{t}=0$ is the year of the pandemic event. Estimates based on $y_{i, t+k}=\alpha_{i}^{k}+\gamma_{t}^{k}+F\left(z_{i t}\right)\left[\beta_{L}^{k} D_{i, t}\right]+$ $\left(1-F\left(z_{i t}\right)\right)\left[\beta_{H}^{k} D_{i, t}\right]+\theta_{L}^{k} X_{i, t}+\varepsilon_{i, t+k}$ (see text and notes to Figures 3 and 4 for details). 
TABLE 1. SPREAD AND SEVERITY OF PANDEMICS: SUMMARY STATISTICS

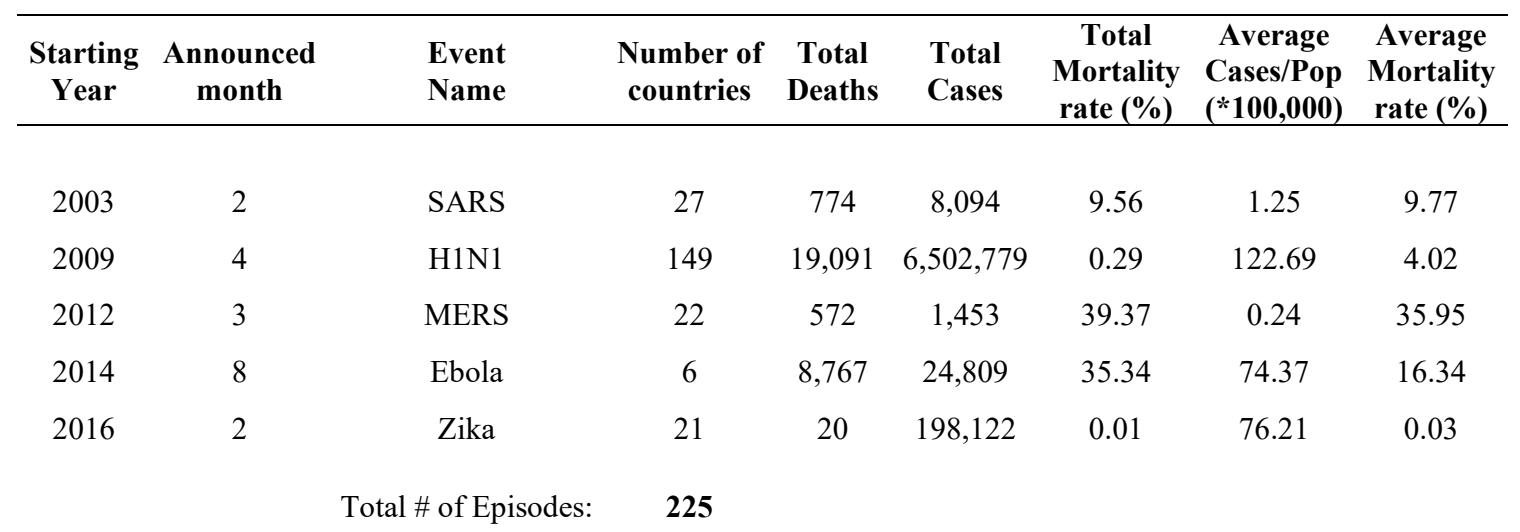

Sources: WHO, Ma, Rogers and Zhou (2020) Furceri and others (2020); ECDC, CDC; PAHO; Wikipedia. Data on population are from the World Bank's World Development Indicator Database.

TABLE 2. DATA SOURCES AND DESCRIPTIVE STATISTICS

\begin{tabular}{llrrcc}
\hline Variable & Source & Obs. & Mean & Std. Dev. & No. of Countries \\
\hline Gini Market & SWIID 8.3 & 5,472 & 45.39 & 6.59 & 177 \\
Gini Net & SWIID 8.3 & 5,472 & 38.38 & 8.73 & 177 \\
Redistribution & SWIID 8.3 & 5,472 & 7.01 & 6.82 & 177 \\
& & & & \\
General government fiscal balance & WEO & 5,242 & -2.69 & 14.88 & 185 \\
& & & & & \\
Capital Health Expenditures & WDI & 3,208 & 0.24 & 0.46 & 180 \\
Current Health Expenditures & WDI & 3,208 & 6.20 & 2.58 & 180 \\
Total Health Expenditures & WDI & 3,208 & 6.44 & 2.68 & 180 \\
\hline N & & & & \\
\hline
\end{tabular}

Note: Fiscal balance and health expenditures are expressed as percent of GDP. 